\title{
Metastatic Leiomyosarcoma of the Spine Updates in Management and Surgical Strategy
}

\author{
Giuseppe Maimone $^{{ }^{*}}$, Nicola Nicassio ${ }^{2}$, Irfan Malik ${ }^{2}$, Mauro Cambria ${ }^{1}$ \\ ${ }^{1}$ Department of Neurosurgery, University Policlinic of Messina, Messina, Italy \\ ${ }^{2}$ Department of Neurosurgery, King's College Hospital, London, UK \\ Email: 'gmaimone@hotmail.com
}

Received August 28, 2013; revised September 28, 2013; accepted October 5, 2013

Copyright (C) 2013 Giuseppe Maimone et al. This is an open access article distributed under the Creative Commons Attribution License, which permits unrestricted use, distribution, and reproduction in any medium, provided the original work is properly cited.

\begin{abstract}
Introduction: Leiomyosarcoma (LMS) is a rare malignant tumor arising from the smooth-muscle cells which rarely metastasizes to the bone and even less is found in the spine as a primary localization. In this article the authors describe a case of a peculiar localization of this neoplasm in the upper thoracic spine which required a tailored surgical treatment. Case Report: A 52-year-old female presented with an 8 weeks' history of gradually worsening myelopathy and sensory level in the upper thoracic spine. Pre-operation MRI scans showed an invasive mass neoplasm at T3 and T4 levels involving the vertebral bodies and pedicles with a significant cord compression. A $360^{\circ}$ two-step approach was performed. The first operation consisted in a T1-T4 decompressive laminectomy with a sub-total tumor resection and pedicle fixation extending from C7 to T5. A second surgical step was performed through an anterior approach in order to improve the amount of tumor removal. Instrument fixation assured the stabilization of the spinal segment. Post-operative scans demonstrated an optimal decompression. Neurological symptoms gradually improved, and the patient benefitted from a gradual reversion of previous symptomatology and could go back to her previous life. Conclusion: LMS represents a challenging tumor due to an extremely aggressive behavior and a considerably high rate of recurrence which requires a tailored approach in terms of surgical strategy and follow-up. A exhaustive review of literature was performed in the attempt to rationalize a surgical strategy and correct management of this extremely rare neoplastic lesion.
\end{abstract}

Keywords: Metastatic Leiomyosarcoma; Spinal Metastasis; Upper Thoracic; Anterior Approach

\section{Introduction}

Leiomyosarcoma (LMS) is a rare mesenchymal tumor arising from smooth muscle cells with a typical malignant behavior and incidence of 0.7 cases per 100,000 persons [1]. The most common localization of this neoplasm, which accounts from $7 \%$ of soft tissue sarcomas, is represented by the uterus where is thought to arise either from the myometrium or the endometrial stroma, the latter when undergoes smooth muscle differentiation [2]. Metastatic spreading is possible, and it often involves soft tissues and internal organs like lungs, liver, retroperitoneal space and skin. LMS metastases to the spine are quite rare even though they represent the most common finding among the osseous tissue localizations [3]. Along with the lumbar tract, upper thoracic spine represents the most observed invasion site [4,5] and may be a severe issue in decision making and in finding the most suitable spinal approach. When the upper thoracic spine is in-

\footnotetext{
"Corresponding author.
}

volved the treatment may be challenging in terms of surgical choice. The current management depends mostly on the spreading of the lesion and the involvement of the vertebral structures along with the entity of the patient's symptoms. Quite often a multi-modality approach with post-adjuvant therapy is strongly advisable.

\section{Case Report}

History and Examination. A 51-year-old female presented in our institution with an 8 week history of gradually worsening back pain and weakness in the lower limbs. Neurological examination revealed a bilateral power deficit in the lower limbs (4/5), a sensory level between T2-T7 and brisk leg reflexes. Clinical examination did not show any spincter impairment. The patient referred to have undergone a hysterectomy in 2010, but she did not provide any clinical documentation.

Investigations. Complete blood count, electrolyte and inflammatory markers were unremarkable. Tumoral 
markers were negative. Full spine MRI scans showed a 6 $\times 6 \times 8 \mathrm{~cm}$ extradural mass, hypointense in $\mathrm{T} 1$ and isointense in T2, moderately enhancing after gadolinium administration. The mass lesion resulted displaced at T3-T4 level with a massive invasion of pedicles and vertebral bodies. A severe cord compression could also be demonstrated mainly at T4 level.

First Surgical Treatment. The patient underwent a first operation consisting in a decompressive laminectomy between T1 and T4 and a subtotal removal of the tumoral mass. Macroscopically the neoplasm appeared as a bulky, highly vascularized, fleshy mass of grey/brownish color. No frozen section were taken. Only a partial excision of the neoplasm was performed due to the high amount of bleeding and the impossibility to achieve a complete debulking of the tumor aiming to relieve the spinal cord compression. The segments involved with the laminectomy were stabilized by the insertion of pedicle screws and rods between C7 (25 mm), T1 (30 mm) and T4 (30 mm).

Histological Findings. Section samples revealed a clear evidence of a malignant tumor composed of intersecting sharply marginated groups of spindle cells suggesting a sarcomatous origin. The tumor nuclei were elongated and blunt with the presence of hyperchromatic and pleomorphic cells, together with a few osteoclast-like giant cells. Some of the tumor cells presented mildly vacuolated cytoplasm, but most of them had eosinophilic cytoplasm. Mitotic figures were common (7 per $10 \mathrm{HPF}$ ) but with no obvious necrosis. Immunohistochemistry revealed strong positivity with SMA and desmin in all tumor cells. Vimentin and EMA were focally positive. Myogenin showed only faint cytoplasmic staining. CD99 was faintly positive. CD34, HMB45, pancytokeratin, S100 and GFAP were negative. Proliferation activity index was $40 \%$ by Ki67.

The presence of a positivity of SMA, desmin and hcaldesmon along with a negative Melan-A was consistent with a smooth muscle tumor. Atypia, mitotic activity and high proliferation index confirmed the malignant origin suggesting a LMS.

Follow-Up. After the first operation, the patient progressively benefitted from a relevant improvement of her neurological symptoms by reaching a restitutio ad integrum. She was discharged 7 days after the operation with a basal steroid medication. A second operation was planned in 4 month time in order to achieve a maximal tumor removal.

Second Surgical Treatment. A 3-month follow-up MRI showed the large tumoral mass mainly invading T3-T4 vertebral bodies (Figure 1). The operation was performed with an anterior approach through a right lateral cervical skin incision. The cervical region was approached until the anterior aspect of C7 and T1 vertebrae and a complete midline sternotomy was performed with a wide exposure of the pericardium. The left innominate vein was isolated and protected while the left carotid was partially mobilized. A safe corridor was created allowing a T3-T4 corpectomy and a maximal resection of the tumoral mass. At the end of the resection, an injection of cement was made to fill the gap left from the space occupying lesion. Screws $(18 \mathrm{~mm})$ and a Depuy Plate were inserted through the vertebrae in the above and below level to secure the stability of the spinal tract (Figure 2). The histopathological report confirmed the precedent one with an increment of the proliferation activity index (50\%).

Outcome and Follow-Up. The patient did not show any neurological deficit and, after the post-operative routine images, she was discharged and come back to her previous life.

\section{Discussion}

LMS is a rare malignant tumor which even rarely metas-

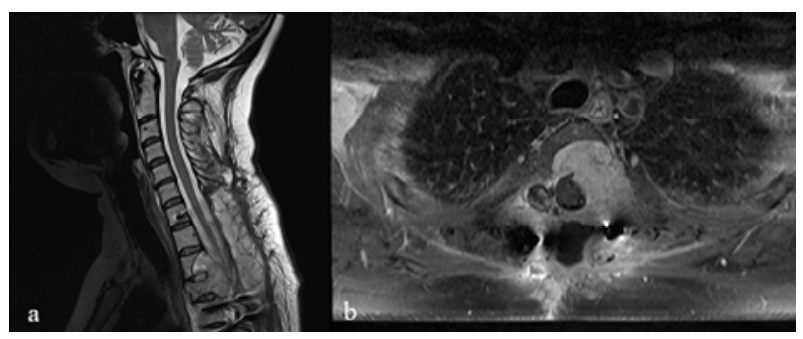

Figure 1. Sagittal and axial T2 WI images showing the metastatic mass at T3-T4 level with a massive invasion of the vertebral body and pedicles which causes a significant spinal cord compression.

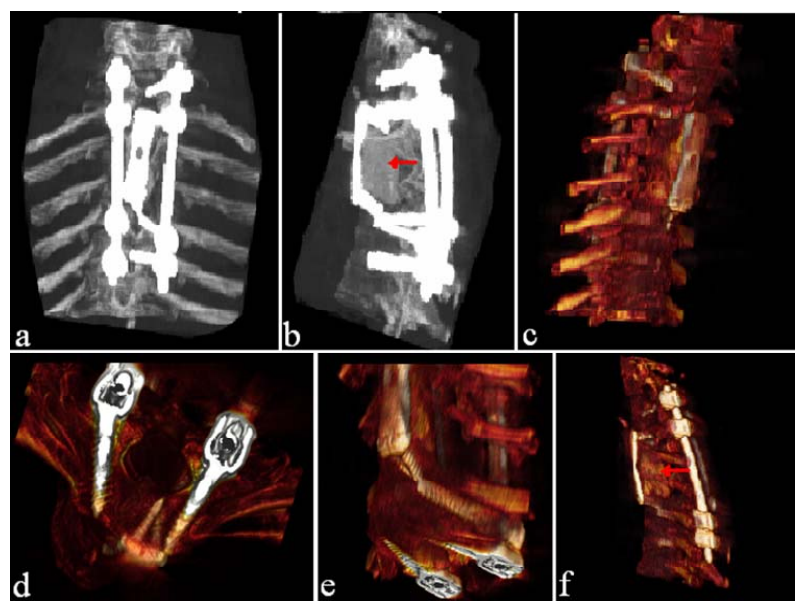

Figure 2. (a)-(f) Images show a tridimensional CT scan showing posterior fixation with insertion of pedicular screws (C7-25 mm, T1-30 mm, T3-30 mm, T4-30 mm) along with an anterior stabilization with aid of plate and screws (T1-T3 Depuy plate with $18 \mathrm{~mm}$ screws). The hypodense images below the anterior plates ((b), (f) with red arrows) represent the cement injection placed to fill the gap after vertebrectomy and tumor debulking. Images (d) and (e) show some particular aspects of screw insertion. 
tasize to the bone being the latter localization a delayed manifestation of its natural progression [6]. Spinal metastases represent the most common bone localizations $[7,8]$ with prevalence in the thoracic and lumbar spine $[4,5]$.

The origin of this neoplasm is controversial; a chromosome aberration may be involved in the benign forms [9] even though it has been hypothesized they could arise from blood vessels [10] or pluripotent mesenchymal cells [11] which may in turn arise from leptomeninx to explain the onset of primary spinal localizations [12]. On MRI scan, it presents as a hypo-isointense homogeneous signal on T1-weighted whereas a hyperintense signal is generally evident in T2-weighted [13]. Differential diagnosis includes neurinomas, neurofibromas, meningiomas, lymphomas, fibrous tumors, ependymomas and other metastatic tumors.

Histologically, LMSs present a wide range of atypia extending from a well-differentiated pattern to an extremely anaplastic one, the latter typical of the most aggressive sarcomas. Cell morphology is quite similar to the benign leiomyoma, consisting in bundles of spindleshaped, smooth cells with oval nucleus and long, slender bipolar cytoplasmic processes. Nuclear atypia, high mitotic index and zonal necrosis confirm the malignant nature of the neoplasm [14,15].

From a review of the literature, we found that primary LMSs arising from the spine and paravertebral muscles are very rare entities with only 14 cases reported according to the best of our knowledge [8,11-13,16-18]. Similarly, metastatic LMSs with spinal localization represent very uncommon findings with just few cases described in literature [3-5,7,8,19-23] as either first presentation or secondary recurrence [24-26]. The main presentation consists in bone invasion and epidural localization. Only in one case an intramedullary extension was demonstrated [27].

Notably, the differentiation between primary and metastatic lesion is not an easy issue for the difficult differential diagnosis with its benign form, the leiomyoma.

This could lead to a wrong diagnosis of a less aggressive lesion, or a primary tumor in place of a secondary one, with severe consequences in terms of correct management and follow-up [6]. In our case, there was no evidence of a primitive tumor, but in the patient's anamnesis a hysterectomy had been performed 2 years before. No further information was provided about the nature of this treatment but for the high prevalence of LMS localization in the uterus we assumed that the spinal lesion was likely to be a secondary process.

Despite the onset of metastasis generally indicates a poor prognosis, as reported by Abeler et al. [28] in a study of more than 400 patients with uterine localization in which the median survival of extrauterine spreading was less than 1 year, other studies highlight better outcomes in terms of disease progression and quality of life [29]. The reason of these discrepancies may be found in the inconstant clinical course of this neoplasm depending on its primary localization, the extent of spinal tract involved and the clinical status of the patient. In our study, we analyzed the current literature in the attempt to find whether a rational clinical management and surgical strategy are suitable for the treatment of metastatic spinal LMS. Due to the rarity of this tumor, an accurate review of the literature showed only few case reports and two series of surgical cases that we report in Table 1. From data analysis, we found that the mean age is $51(25-83)$ with a M:F of 0.25. As expected, there is a clear evidence of uterus primary localization $(13 / 20-65 \%$, Figure 3(a)); the main neurological presenting symptom is back/ lower limb pain $(16 / 20-80 \%)$, followed by myelopathy signs/ paraplegia (10/20—50\%) and severe sensory disturbance (8/20-40\%) as showed in Figure 3(b). The radiological findings indicate a clear prevalence for thoracic localization (14/20-70\%) with the remaining 30\% represented by lumbar invasion (6/20-30\%, Figure 3(c)). Regarding the surgical treatment, a wide range of surgical approaches has been performed including plain laminectomy, vertebrectomy and segment fixation according to the extent and location of metastatic lesions. The outcome shows a general improvement of the neurological symptoms regarding mainly pain relief and myelopathic signs. Zievacs et al. [5] reported a general improvement consisting in 1 or 2 incremental points according to the Nurick grade and up to 5 points according to the VAS scale (Table 2). Even though the median survival seems not to be particularly affected by the post-adjuvant therapy, chemotherapy seems to be regularly adopted in $82 \%$ of documented cases (14/17), whereas only $47 \%$ had radiotherapy (8/17). The median survival shows some discrepancies in the surgical cases. In fact, in a surgical series of 5 patients, Elhammady [4] documents a considerably long mean survival time (8.6 years) with 2 cases consisting in 36 and 42 months follow-up patients still alive. If we compare this data with the series of Ziewacz and other case reports which a documented follow-up $[3,7,22]$, the survival rate falls down to a mean value of 10.7 months. Apart from the relatively short number of cases of the first series that may not be statistically significant, this difference of data could be explained with a more aggressive course of the tumor in the second group, confirmed by the higher rate of recurrence (62\% Ziewacz versus $40 \%$ Elhammady), or the delayed time of treatment in case of misdiagnosis with a benign form. This could be explained in a relatively mild symptomatology that in some cases consists only in back pain (Table 1) above all in cases where spine metastasis is the first manifestation of LMS. In Ziewacz series [5] 4 out of 5 
Table 1. Literature review of surgically treated cases of metastatic LMS in the spine.

\begin{tabular}{|c|c|c|c|c|c|c|c|c|c|c|c|c|c|}
\hline Author & $\begin{array}{l}\text { No } \\
\text { Pt }\end{array}$ & Pt & Sex & Age & Primary & Spine & $\begin{array}{l}\text { Clin. } \\
\text { Pres. }\end{array}$ & $\begin{array}{l}\text { Vertebra } \\
\text { Involv. }\end{array}$ & Operation & $\begin{array}{l}\text { Ch./ } \\
\text { RT }\end{array}$ & $\begin{array}{c}\text { Outcome } \\
\text { (Nurick/VAS) }\end{array}$ & $\begin{array}{l}\text { Recur./ } \\
\text { Redo } \\
\text { Surgery }\end{array}$ & Survival \\
\hline $\begin{array}{l}\text { Amesen } \\
\text { et al., } \\
1992\end{array}$ & 1 & - & $\mathrm{F}$ & 55 & Uterus & T11-T12 & $\begin{array}{l}\text { Leg pain/ } \\
\text { paraplegia }\end{array}$ & $\begin{array}{l}\text { Destructive } \\
\text { pst. elem. }\end{array}$ & Laminectomy & $\mathrm{Y} / \mathrm{N}$ & Improvement & No f/u & $\begin{array}{l}6 \mathrm{mo} \mathrm{f} / \mathrm{u} \\
\text { alive }\end{array}$ \\
\hline $\begin{array}{l}\text { Shapiro } \\
\text { et al., } \\
1992\end{array}$ & 1 & - & $\mathrm{F}$ & 64 & Uterus & $\mathrm{T} 5$ & $\begin{array}{c}\text { Progressive } \\
\text { paraplegia }\end{array}$ & $\begin{array}{c}\text { Lamina } \\
\text { canal inv. }\end{array}$ & Laminectomy & $\mathrm{Y} / \mathrm{N}$ & Improvement & No & $\begin{array}{l}1 \mathrm{yr} \\
\text { alive }\end{array}$ \\
\hline $\begin{array}{l}\text { Takemori } \\
\text { et al., } \\
1993\end{array}$ & 1 & - & $\mathrm{F}$ & 47 & Uterus & $\mathrm{T}-8$ & Back pain & $\begin{array}{l}\text { Vertebral } \\
\text { body }\end{array}$ & $\begin{array}{l}\text { Corpectomy } \\
\text { pst. stabiliz. }\end{array}$ & $\mathrm{Y} / \mathrm{N}$ & Improvement & No f/u & No f/u \\
\hline $\begin{array}{l}\text { Nanassis } \\
\text { et al., } \\
1999\end{array}$ & 1 & - & $\mathrm{F}$ & 46 & Uterus & T2-T3 & $\begin{array}{l}\text { Back pain/ } \\
\text { paraplegia }\end{array}$ & $\begin{array}{c}\text { Extradural } \\
\text { pst. }\end{array}$ & $\begin{array}{c}\mathrm{T} 2-\mathrm{T} 3 \\
\text { laminectomy }\end{array}$ & $\mathrm{N} / \mathrm{N}^{*}$ & Recovery & $\begin{array}{l}\text { Metastatic } \\
\text { disease }\end{array}$ & $\begin{array}{c}9 \text { mo } \\
\text { Unoper. }\end{array}$ \\
\hline $\begin{array}{l}\text { Botwin } \\
\text { et al., } \\
2000\end{array}$ & 1 & - & $\mathrm{F}$ & 50 & Vagina & L3 & Leg pain & $\begin{array}{l}\text { Vertebral } \\
\text { body }\end{array}$ & Laminectomy & $\mathrm{Y} / \mathrm{Y}$ & Improvement & - & 6 months \\
\hline $\begin{array}{l}\text { Ido et al., } \\
\quad 2002\end{array}$ & 1 & - & M & 83 & Thigh & $\mathrm{T}-7$ & $\begin{array}{l}\text { Back pain } \\
\text { parapar. }\end{array}$ & $\begin{array}{l}\text { Vertebral } \\
\text { body }\end{array}$ & $\begin{array}{l}\text { Laminectomy } \\
\text { pst stabiliz. }\end{array}$ & - & Improvement & No f/u & No f/u \\
\hline \multirow[t]{5}{*}{$\begin{array}{l}\text { Elhammady } \\
\text { et al., } 2007\end{array}$} & 5 & A & $\mathrm{F}$ & 45 & Uterus & L2 & Back pain & $\begin{array}{l}\text { Vertebral } \\
\text { body }\end{array}$ & $\begin{array}{l}\text { Corpectomy } \\
\text { pst stabiliz. }\end{array}$ & $\mathrm{Y} / \mathrm{Y}$ & Improvement & $\begin{array}{c}\text { Yes/ } \\
\text { chemio }\end{array}$ & $\begin{array}{l}42 \text { mo } \\
\text { alive }\end{array}$ \\
\hline & & B & $\mathrm{F}$ & 46 & Uterus & T11 \& L2 & $\begin{array}{l}\text { Back pain } \\
\text { leg numb. }\end{array}$ & $\begin{array}{l}\text { Vertebral } \\
\text { body }\end{array}$ & $\begin{array}{l}\text { Transped dec } \\
\text { pst stabiliz. }\end{array}$ & - & Improvement & No & $\begin{array}{l}36 \text { mo } \\
\text { alive }\end{array}$ \\
\hline & & $\mathrm{C}$ & $\mathrm{F}$ & 36 & Uterus & L-5 & $\begin{array}{l}\text { Back pain } \\
\text { leg pain }\end{array}$ & $\begin{array}{l}\text { Vert. body } \\
\text { epidural }\end{array}$ & $\begin{array}{l}\text { Laminectomy } \\
\text { pst stabiliz. }\end{array}$ & $\mathrm{Y} / \mathrm{N}$ & Improvement & Yes/no & 9 years \\
\hline & & $\mathrm{D}$ & $\mathrm{F}$ & 42 & Uterus & L3 & $\begin{array}{c}\text { Pain } \\
\text { leg weakn }\end{array}$ & Vert. body & $\begin{array}{l}\text { Laminectomy } \\
\text { pst. Stabiliz. }\end{array}$ & - & Improvement & No & 8 years \\
\hline & & $\mathrm{E}$ & $\mathrm{F}$ & 47 & Retrop. & $\begin{array}{c}\text { T3, } \\
\text { T11-T12, } \\
\text { L1-2 }\end{array}$ & Back pain & Multilocation & $\begin{array}{c}\text { Transped dec } \\
\text { T3 corpect } \\
\text { T1-T6 pstlat fusion }\end{array}$ & $\mathrm{Y} / \mathrm{N}$ & Improvement & No & 8 years \\
\hline \multirow{7}{*}{$\begin{array}{c}\text { Ziewacz } \\
\text { et al., } 2012\end{array}$} & & B & $\mathrm{F}$ & 61 & $\begin{array}{l}\text { Chest } \\
\text { wall }\end{array}$ & L1 & Back pain & $\begin{array}{l}\text { Vert. body/ } \\
\text { pedicles }\end{array}$ & $\begin{array}{l}\text { Laminectomy } \\
\text { pst fusion }\end{array}$ & $\mathrm{Y} / \mathrm{Y}$ & Improvement & $\mathrm{N}$ & $\begin{array}{l}10 \text { mo } \\
\text { alive }\end{array}$ \\
\hline & & $\mathrm{C}$ & $\mathrm{F}$ & 35 & Uterus & T1-T3 & Arm pain & $\begin{array}{l}\text { Vert. body/ } \\
\text { pedicles }\end{array}$ & $\begin{array}{l}\text { T-2 hemilami } \\
\text { pst fusion }\end{array}$ & $\mathrm{Y} / \mathrm{Y}$ & Improvement & $\mathrm{Y} / \mathrm{Y}$ & $11.5 \mathrm{mo}$ \\
\hline & & $\mathrm{D}$ & $\mathrm{F}$ & 57 & Uterus & $\mathrm{T}-1$ & $\begin{array}{l}\text { Chest pain } \\
\text { funct loss }\end{array}$ & $\begin{array}{l}\text { Vert. body/ } \\
\text { lamina }\end{array}$ & $\begin{array}{l}\text { Laminectomy } \\
\text { pst fusion }\end{array}$ & $\mathrm{Y} / \mathrm{Y}$ & Improvement & $\mathrm{Y} / \mathrm{Y}$ & $20.3 \mathrm{mo}$ \\
\hline & & $\mathrm{E}$ & $\mathrm{F}$ & 57 & Uterus & L4-S1 & $\begin{array}{c}\text { Paresth./ } \\
\text { pain }\end{array}$ & Lamina & Hemilami & $\mathrm{Y} / \mathrm{Y}$ & Improvement & $\mathrm{Y} / \mathrm{Y}$ & $23.0 \mathrm{mo}$ \\
\hline & & $\mathrm{F}$ & $\mathrm{F}$ & 51 & Uterus & $\mathrm{T} 2-\mathrm{T} 4$ & $\begin{array}{l}\text { Leg weakn/ } \\
\text { numbn }\end{array}$ & Lamina & $\begin{array}{l}\text { Hemilami } \\
\text { pst fusion }\end{array}$ & $\mathrm{N} / \mathrm{N}$ & Improvement & $\mathrm{N}$ & $3.3 \mathrm{mo}$ \\
\hline & & G & M & 55 & Retrop. & T10-12 & $\begin{array}{l}\text { Back pain } \\
\text { funct loss }\end{array}$ & $\begin{array}{l}\text { Vert. body/ } \\
\text { lamina }\end{array}$ & $\begin{array}{l}\text { Laminectomy } \\
\text { pst fusion }\end{array}$ & $\mathrm{Y} / \mathrm{Y}$ & Improvement & $\mathrm{Y} / \mathrm{N}$ & $5.7 \mathrm{mo}$ \\
\hline & & $\mathrm{H}$ & $\mathrm{M}$ & 66 & Knee & $\mathrm{T}-4$ & Func loss LL & Lamina & Laminectomy & $\mathrm{Y} / \mathrm{N}$ & Improvement & $\mathrm{N}$ & $3.3 \mathrm{mo}$ \\
\hline Present case & 1 & - & $\mathrm{F}$ & 52 & Uterus & T3-T4 & $\begin{array}{l}\text { Leg weakn } \\
\text { func loss }\end{array}$ & $\begin{array}{l}\text { Vert. body } \\
\text { pedicles }\end{array}$ & $\begin{array}{l}\text { Laminectomy } \\
\text { ant/pst fixation }\end{array}$ & $\mathrm{Y} / \mathrm{Y}$ & Improvement & $\mathrm{N}$ & $\begin{array}{l}6 \text { mo } \\
\text { alive }\end{array}$ \\
\hline
\end{tabular}

*Treatment refused by the patient.

Table 2. Nurick scale of mielopathy [30].

\begin{tabular}{cr}
\hline Grade & Symptoms \\
\hline $\mathbf{0}$ & Signs or symptoms of root involvement but without evidence of spinal cord disease. \\
$\mathbf{2}$ & Signs of spinal cord disease but no difficulty in walking. \\
$\mathbf{3}$ & Slight difficulty in walking which does not prevent full-time employment. \\
$\mathbf{4}$ & Difficulty in walking which prevented full time employment or the ability to do all housework, \\
$\mathbf{5}$ & but which was not so severe as to require someone else's help to walk. \\
\hline
\end{tabular}




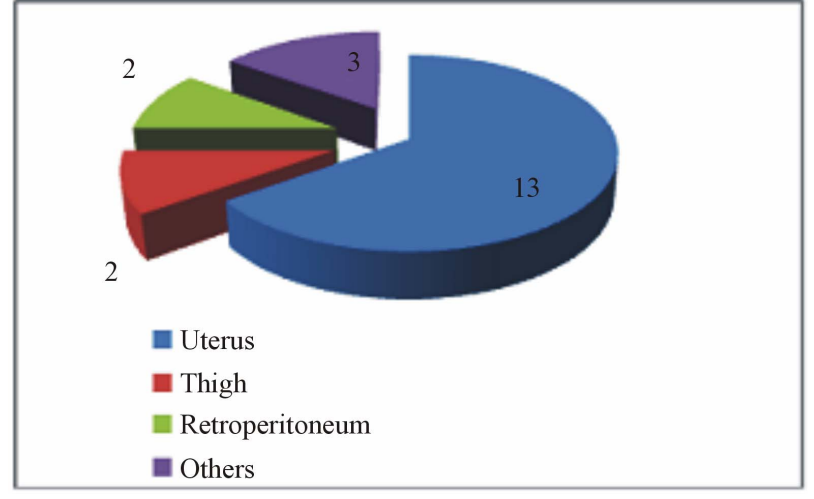

(a)

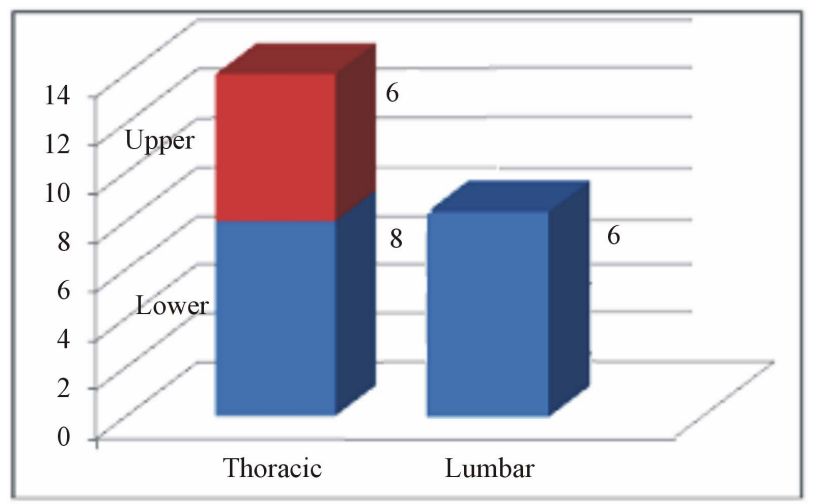

(b)

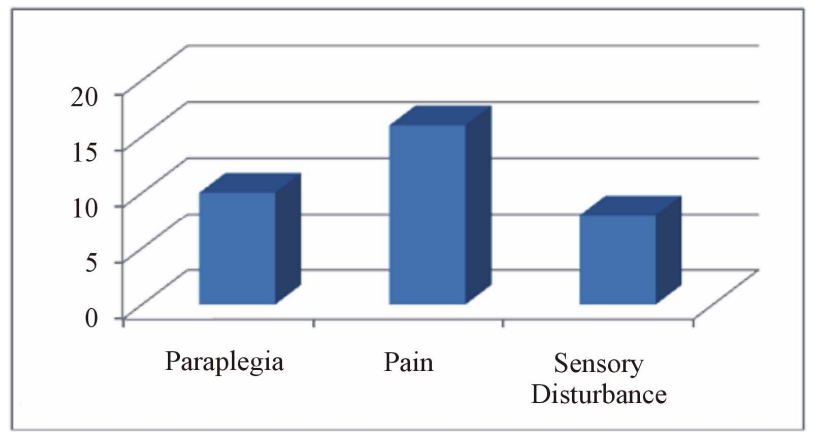

(c)

Figure 3. (a) Primary localization of LMS in series review; (b) Neurological presenting symptoms; (c) Distribution of metastasis in the spine in agreement with the literature data.

patients with the onset of recurrence were re-operated and 3 of them had an improvement of symptoms. In our case, the early onset of neurological signs allowed a prompt diagnosis and an individually tailored treatment. To our knowledge this is the first case of Thoracic LMS treated with a $360^{\circ}$ two-step approach which involved a tailored surgical strategy in terms of the anterior approach of the upper thoracic segment. During the operation, the assistance of thoracic surgeon was required for the sternotomy and the approach to the mediastinum area. The placement of cement to fill the gap left by tumor removal and the spine fixation with an anterior plate and screws provided a correct stabilization of the thoracic level. The relative high rate of tumor recurrence observed in literature and the increase of proliferation activity resulted in the second specimen of our case justified such aggressive surgical treatment.

\section{Conclusion}

Like primary spinal localization, metastatic LMS represents an exceptionally rare finding among the metastatic chord compression lesions. The osteolytic nature, the brisk proliferative activity and the relatively high rate of recurrences of this tumor justifies an aggressive approach and an early treatment of recurrences. Surgery decompression seems to reduce pain symptomatology and prevent from worsening of myelopathy. For the above reasons, spinal fixation should be tailored according to the individual cases. Chemotherapy seems to play a role more than radiotherapy for which the tumor seems relatively radioresistant. A further effort should also be taken with regard to the correct diagnosis which assures the correct management of this rare but highly serious pathology.

\section{REFERENCES}

[1] F. Ducimetière, A. Lurkin, D. Ranchère-Vince, A. V. Decouvelaere, M. Péoc’h, L. Istier, et al., "Incidence of Sarcoma Histotypes and Molecular Subtypes in a Prospective Epidemiological Study with Central Pathology Review and Molecular Testing," PLoS One, Vol. 6, No. 8, 2011, Article ID: e20294.

http://dx.doi.org/10.1371/journal.pone.0020294

[2] C. P. Crum, “The Femal Genital Tract,” In: R. Cotran, V. Kumar and C. T. Robbins, "Pathologic Basis of Disease," 6th Edition, W.B. Saunders Company, Philadelphia, 2009.

[3] K. Nanassis, C. Alexiadou-Rudolf and P. Tsitsopoulos, "Spinal Manifestation of Metastasizing Leiomyosarcoma,” Spine, Vol. 24, No. 10, 1999, pp. 987-989. http://dx.doi.org/10.1097/00007632-199905150-00011

[4] M. S. Elhammady, G. R. Manzano, N. Lebwoh and A. D. Levi, "Leiomyosarcoma Metastases to the Spine. Case Series and Review of the Literature," Journal of Neurosurgery, Vol. 6, No. 2, 2007, pp. 178-183. http://dx.doi.org/10.3171/spi.2007.6.2.178

[5] J. E. Ziewacz, L. Darryl, F. La Marca and P. Park, “Outcomes after Surgery for Spinal Metastatic Leiomyosarcoma," Journal of Neurosurgery Spine, Vol. 17, No. 5, 2012, pp. 432-437. http://dx.doi.org/10.3171/2012.8.SPINE12331

[6] V. L. Fornasier and D. Paley, "Leiomyosarcoma in Bone: Primary or Secondary? A Case Report and Review of the Literature,” Skeletal Radiology, Vol. 10, No. 3, 1983, pp. 147-153. http://dx.doi.org/10.1007/BF00357768

[7] K. Ido, H. Matsuoka, M. Yoshida and H. Urushidani, "Paraparesis Due to Spinal Leiomyosarcoma Lesion in 
the Thoracic Spine Accompanied by Two Leiomyosarcoma Lesions in the Back and the Thigh over an Interval of 4 Years," Journal of Clinical Neuroscience, Vol. 9, No. 3, 2002, pp. 325-328.

http://dx.doi.org/10.1054/jocn.2001.0989

[8] S. Shapiro, "Myelopathy Secondary to Leiomyosarcoma of the Spine. Case Report,” Spine, Vol. 17, No. 2, 1992, pp. 249-251.

http://dx.doi.org/10.1097/00007632-199202000-00025

[9] B. J. Quade, "Pathology, Cytogenetics, and Molecular Biology of Uterine Leiomyomas and Other Smooth Muscle Lesions," Current Opinion in Obstetrics and Gynecology, Vol. 7, No. 1, 1995, p. 35.

[10] H. Shimoda, K. Oka, S. Otani, H. Hakozaki, T. Yoshimura, H. Okazaki, et al., "Vascular Leiomyosarcoma Arising from the Inferior Vena Cava Diagnosed by Intraluminal Biopsy," Virchows Arch, Vol. 433, No. 1, 1998, pp. 97-100.

http://dx.doi.org/10.1007/s004280050223

[11] J. De Vries, R. Scheremet, M. Altmannsberger, R. Michilli, A. Lindemann and W. Hinkelbein, "Primary Leiomyosarcoma of the Spinal Leptomeninges,” Journal of Neuro-Oncology, Vol. 18, No. 1, 1994, pp. 25-31. http://dx.doi.org/10.1007/BF01324600

[12] H. Ochiai, Y. Yamakawa, T. Fukushima, H. Yamada and T. Hayashi, "Primary Leiomyosarcoma of the Cervical Spine Causing Spontaneous Compression Fracture: Report of an Autopsy Case-Case Report," Neuropathology, Vol. 20, No. 1, 2000, pp. 60-64.

http://dx.doi.org/10.1046/j.1440-1789.2000.00279.x

[13] T. H. Lo, W. J. van Rooij, J. L. Teepen and I. T. Verhagen, "Primary Leiomyosarcoma of the Spine," Neuroradiology, Vol. 37, No. 6, 1995, pp. 465-467. http://dx.doi.org/10.1007/BF00600095

[14] J. Buscema, et al., "Epithelioid Leiomyosarcoma," Cancer, Vol. 57, No. 6, 1986, p. 1192. http://dx.doi.org/10.1002/1097-0142(19860315)57:6<119 2::AID-CNCR2820570621>3.0.CO;2-B

[15] S. W. Bell, et al., "Problematic Uterine Smooth Muscle Neoplasms. A Clinicopathologic Study of 213 Cases," American Journal of Surgical Pathology, Vol. 18, No. 6, 1994, p. 535.

http://dx.doi.org/10.1097/00000478-199406000-00001

[16] P. Krepler, R. Windhager, W. Bretschneider, C. D. Toma and R. Kotz, "Total Vertebrectomy for Primary Malignant Tumours of the Spine," Journal of Bone and Joint Surgery, Vol. 84B, No. 5, 2002, pp. 712-715. http://dx.doi.org/10.1302/0301-620X.84B5.12684

[17] A. G. Laurence, "Marshman. Primary Extradural Epithelioid Leiomyosarcoma of the Cervical Spine: Case Report and Literature," Neurosurgery, Vol. 57, No. 2, 2005, p. 372. http://dx.doi.org/10.1227/01.NEU.0000166695.89757.A4

[18] M. Potsi, P. Stavrinou, N. Patsinakidis, D. Hatzibougias, N Foroglou, G. Karayanopoulou, et al., "Primary Osseous Leiomyosarcoma of the Spine: A Rare Entity-
Case Report and Review of the Literature,” Journal of Neurological Surgery Part A: Central European Neurosurgery, Vol. 73, No. 4, 2012, pp. 238-242.

[19] L. U. Gardner, “A Case of Metastatic Leiomyosarcoma Primary in the Uterus," Journal of Medical Research, Vol. 36, No. 1, 1917, p. 19.

[20] R. A. Willis, "The Spread of Tumours in the Human Body,” 3rd Edition, Butterworths, London, 1973, p. 234.

[21] M. A. Arnesen and J. W. Jones, "Spindle Cell Neoplasm of the Thoracic Spine,” Ultrastructural Pathology, Vol. 16, No. 1-2, 1992, pp. 29-34. http://dx.doi.org/10.3109/01913129209074547

[22] K. P. Botwin and P. J. Zak, "Lumbosacral Radiculopathy Secondary to Metastatic Uterine Leiomyosarcoma: A Case Report,” Spine (Phila Pa 1976), Vol. 25, No. 7, 2000, pp. 884-887.

[23] H. K. Sucu, H. Bezircioglu and T. Rezanko, "Partial Spondylectomy for Primary Leiomyosarcoma of C2 Vertebra,” Spine (Phila Pa 1976), Vol. 36, No. 21, 2011, pp. E1422-E1426.

[24] L. L. Robbins, "Roentgenologic Demonstration of Spinal Metastases from Leiomyosarcoma of the Uterus," Archives of Surgery, Vol. 47, No. 5, 1943, p. 463. http://dx.doi.org/10.1001/archsurg.1943.01220170046003

[25] M. Takemori, R. Nishimura, K. Sugimura and M. Mitta, "Thoracic Vertebral Bone Metastasis from Uterine Leiomyosarcoma," Gynecologic Oncology, Vol. 51, No. 2, 1993, pp. 244-247. http://dx.doi.org/10.1006/gyno.1993.1280

[26] E. Schjott-Rivers, “Sarcoma of the Uterus," Acta Obstetricia et Gynecologica Scandinavica, Vol. 28, No. 3-4, 1949, pp. 418-425. http://dx.doi.org/10.3109/00016344909155701

[27] L. A. Tan, M. K. Kasliwal, S. Nag and J. E. O’Toole, “A Rare Intramedullary Spinal Cord Metastasis from Uterine Leiomyosarcoma,” Journal of Clinical Neuroscience, Vol. 20, No. 9, 2013, pp. 1309-1312. http://dx.doi.org/10.1016/j.jocn.2012.09.006

[28] V. M. Abeler, O. Røyne, S. Thoresen, H. E. Danielsen, J. M. Nesland and G. B. Kristensen, "Uterine Sarcomas in Norway. A Histopathological and Prognostic Survey of a Total Population from 1970 to 2000 Including 419 Patients," Histopathology, Vol. 54, No. 3, 2009, pp. 355364. http://dx.doi.org/10.1111/j.1365-2559.2009.03231.x

[29] C. Svarvar, T. Böhling, O. Berlin, P. Gustafson, G. Follerås, B. Bjerkehagen, et al., "Clinical Course of Nonvisceral Soft Tissue Leiomyosarcoma in 225 Patients from the Scandinavian Sarcoma Group," Cancer, Vol. 109, No. 2, 2007, pp. 282-291. http://dx.doi.org/10.1002/cncr.22395

[30] S. Nurick, "The Pathogenesis of the Spinal Cord Disorder Associated with Cervical Spondylosis,” Brain, Vol. 95, No. 1, 1972, pp. 87-100. http://dx.doi.org/10.1093/brain/95.1.87 